\title{
Greenfield or Acquisition Entry? An Impact of Foreign Direct Investment on the Competitiveness of Polish Investors
}

\author{
Małgorzata Jaworek, Włodzimierz Karaszewski, Małgorzata Szałucka
}

\section{A B S T R A C T}

Objective: The purpose of this article is to determine the impact of Polish FDI companies on their competitiveness, depending on their establishment mode choice in the host country (greenfield investment vs. acquisition).

Research Design \& Methods: The study used a direct interview method. The results were analysed using impact indicators $(w)$ calculated as the arithmetic mean of numerical values assigned to each response as well as Fisher's exact test. Statistical calculations were performed using the IBM SPSS Statistics software version 21.0.0.1.

Findings: The impact of FDI on investor competitiveness in relation to the main competitors operating on the home market and on foreign markets depends on FDI entry mode (greenfield investment vs. acquisition), among other things.

Implications \& Recommendations: The results of this study may be the starting point for further research on the impact of FDI on competitiveness, particularly through foreign acquisitions. It should be assumed that as Polish companies gain experience on the international stage, this mode of entry will be chosen by investors more frequently.

Contribution \& Value Added: The uniqueness of the following study is in the presentation of the results of original empirical research, which demonstrate the relationship between the foreign establishment mode choice (greenfield investment vs. acquisition) and the competitiveness of investing companies. Ex post evaluations were taken into account while forming the conclusions.

\begin{tabular}{ll}
\hline Article type: & research paper \\
Keywords: & international business; FDI; establishment mode choice, greenfield; \\
& acquisition; competitiveness
\end{tabular}

JEL codes:

F21, F23

\section{Suggested citation:}

Jaworek, M., Karaszewski, W., \& Szałucka, M. (2018). Greenfield or Acquisition Entry? An Impact of Foreign Direct Investment on the Competitiveness of Polish Investors. Entrepreneurial Business and Economics Review, 6(2), 137-152. https://doi.org/10.15678/EBER.2018.060207 


\section{INTRODUCTION}

The research on Foreign Direct Investment (FDI) among Polish enterprises has its justification, among other things, in their increasing investment activity abroad. This is evidenced by the growing value of Polish FDI outward stocks, as well as an increasing number of enterprises with foreign entities. The Central Statistical Office data indicates that in the period 2009-2015 alone the number of companies based in Poland and holding entities abroad increased by $35 \%$. During this time, the number of foreign entities increased by almost $50 \%$. The vast majority of foreign entities are direct investment companies. Out of the total number of foreign entities having capital invested by companies domiciled in Poland as many as $82.3 \%$ were entities with a $50 \%$ share of that capital or more (Central Statistical Office, 2017).

The purpose of this article is to determine the impact of FDI made by Polish companies on their competitiveness, depending on their foreign establishment mode choice (greenfield investment vs. acquisition).

The following research hypotheses guided the direction of this study.

H1: The evaluation of FDI influence on the competitiveness of Polish enterprises on the home market and on foreign markets depends on the foreign establishment mode choice.

H2: The benefits associated with the impact of FDI on the individual components of the competitiveness potential depend on the foreign establishment mode choice.

The article is structured as follows. First, the authors provide a brief overview of the theoretical approach to FDI establishment modes in foreign markets with a review of the literature. Data and research methods follow in the next section. The authors then present the results of the study and conclude with a discussion and appraisal including suggestions for future research.

\section{LITERATURE REVIEW}

\section{FDI Establishment Mode Strategy}

One of common areas of research is the problem of FDI location in the process of company internationalisation, including establishment modes in foreign markets. This can be attributed, among other things, to the increased investment activity among enterprises in the form of foreign direct investment observed over the last few decades (UNCTAD, 2016).

By making the decision to enter foreign markets through foreign direct investment, potential investors must decide on the establishment mode strategy, that is decide whether it should take the form of an investment from scratch (greenfield investment), or whether it is to be made by taking over part or all of the equity of a company which is already active on the market (acquisition). Greenfield investment involves the creation of a new affiliate abroad, which may mean the construction and furnishing of the necessary facilities: a factory, a warehouse, office space, etc. A foreign affiliate established via a greenfield investment can take the form of either a wholly-owned subsidiary or a joint venture. An acquisition is an alternative way to enter a foreign market and 
involves the purchase of part or all of the shares of a company located abroad. Sometimes acquisitions are analysed together with mergers as one form of investment - this is how FDI entry modes are analysed in global investment reports published by UNCTAD ${ }^{1}$ as well as in some other publications (Bruning, Turtl, \& Buhr, 1997). However, the majority of empirical studies in this area use the distinction between greenfield investments and acquisitions, which was also adopted in this article.

The choice of a foreign establishment mode in foreign markets affects both current and future results of the company making the investment as well as the foreign subsidiary (Shaver, 1998; Shrader, 2001; Szałucka, 2008; Szałucka, 2010). It is therefore extremely important to analyse in depth potential benefits and risks which a given choice may entail. When deciding on the foreign establishment mode, investors should be aware that the consequences of their mistakes can be very severe and irreversible.

The available literature on the subject includes numerous research papers which discuss the question of foreign establishment mode choice (e.g. Hennart \& Park, 1993; Brouthers \& Brouthers, 2000; Datta, Herrmann, \& Rasheed, 2002; Werner, 2002; Larimo, 2003; Shimizu, Hitt, Vaidyanath, \& Pisano, 2004; Brouthers \& Hennart, 2007; Gorynia, 2007; Slangen \& Hennart, 2007; Slangen \& Hennart, 2008; Demirbag, Tatoglu, \& Glaister, 2008; Demirbag, Tatoglu, \& Glaister, 2009; Arslan \& Larimo, 2011; Slangen, 2011; Jiménez-Burillo \& Jiménez-Moreno, 2013; Kowalewski \& Radło, 2014; Gorynia, Nowak, Trąpczyński, \& Wolniak, 2015a; Gorynia, Nowak, Trąpczyński, \& Wolniak, 2015b; Shen \& Puig, 2017; Holtbrügge \& Berningn, 2018). They focus primarily on identifying the determinants of the choice between alternative capital investment options available on the host market.

The research results show that the choice between greenfield investment and acquisition depends on many different, sometimes interrelated factors. They can be divided into four main groups, namely factors relating to the investing company (the parent company), the subsidiary, the industry and the host country (Slangen \& Hennart, 2007). The large number of factors that impact the decision on the establishment mode and the resulting difficulty and complexity of the decision making process imply that investors must take into account a number of factors resulting from theoretical perspectives including transaction cost theory (Caves \& Mehra, 1986; Zejan, 1990; Hennart \& Park, 1993; Cho \& Padmanabhan, 1995; Hennart, Larimo, \& Chen, 1996; Brouthers \& Brouthers, 2000; Larimo, 2003; Wach, 2012, pp. 95-96; Daszkiewicz \& Wach, 2013, pp. 43-44), the organisational-learning perspective (Padmanabhan \& Cho, 1999; Barkema \& Vermeulen, 1998; Vermeulen \& Barkema, 2001), the industrial organisation perspective (Caves \& Mehra, 1986; Hennart \& Park, 1993; Hennart, Larimo, \& Chen, 1996), institutional theory (Brouthers \& Brouthers, 2000; Harzing, 2002) and information economics (Hennart \& Park, 1993; Hennart et al. 1996). It should be noted, however, that the problem is much more widely studied by researchers and there have been many attempts in the literature to clarify this issue based on other theories as well (Dikova \& Brouthers, 2016).

Among the most frequently quoted and studied factors which impact the investing company's choice of the establishment mode are the size of the investing company (Barkema \& Vermeulen, 1998; Shaver, 1998; Cho \& Padmanabhan, 1995; Padmanabhan \& Cho, 1999; Larimo, 2003), its international experience (Cho \& Padmanabhan, 1995;

\footnotetext{
${ }^{1}$ This division is also mentioned in the UNCTAD publication on foreign direct investment statistics and on transnational corporation activities (UNCTAD, 2009).
} 
Padmanabhan \& Cho, 1999; Barkema \& Vermeulen, 1998; Shaver, 1998; Larimo, 2003), its experience in investing in the host country (Hennart \& Park, 1993; Shaver, 1998; Larimo, 2003), its experience in applying a given establishment mode (Padmanabhan \& Cho, 1999; Slangen \& Hennart, 2007), the level of product/company diversification (Caves \& Mehra, 1986; Zejan, 1990; Hennart \& Park, 1993; Cho \& Padmanabhan, 1995; Padmanabhan \& Cho, 1999; Harzing, 2002; Larimo, 2003; Slangen \& Hennart, 2008), the company's international strategy (Harzing, 2002), and the level of technological intensity and complexity (Hennart \& Park, 1993; Cho \& Padmanabhan, 1995; Padmanabhan \& Cho, 1999; Shaver, 1998; Brouthers \& Brouthers, 2000; Harzing, 2002; Larimo, 2003). The ownership structure of a subsidiary (Caves \& Mehra, 1986; Barkema \& Vermeulen, 1998; Larimo, 2003; Demirbag et al., 2008; Slangen, 2011), its size (Caves \& Mehra, 1986; Slangen, 2013) and the level of its autonomy (Demirbag et al., 2008; Slangen \& Hennart, 2008; Slangen, 2011; 2013) are indicated in the literature of the subject as factors determining the establishment mode in a foreign market connected with a subsidiary.

The research results also show that the probability of choosing a particular mode of establishment in a foreign market can be increased or decreased by the following factors at the industry level: the growth rate of the industry/market (Caves \& Mehra, 1986; Hennart \& Park, 1993; Shaver, 1998; Brouthers \& Brouthers, 2000; Slangen \& Hennart, 2008; Slangen, 2011), the level of concentration (Caves \& Mehra, 1986; Hennart \& Park, 1993; Shaver, 1998), technological intensity (Caves \& Mehra, 1986) and the intensity of advertising (Caves \& Mehra, 1986). An important group of determinants which impact the choice of the foreign establishment mode are factors at a country level, such as cultural differences (Cho \& Padmanabhan, 1995; Padmanabhan \& Cho, 1999; Barkema \& Vermeulen, 1998; Brouthers \& Brouthers, 2000; Lamiro, 2003; Demirbag et al., 2008; Slangen, 2011), the rate of the economic growth (Zejan, 1990; Barkema \& Vermeulen, 1998; Lamiro, 2003; Demirbag et al., 2008); economic development (Zejan, 1990; Barkema \& Vermeulen, 1998; Slangen, 2013), legal limitations/barriers (Cho \& Padmanabhan, 1995; Padmanabhan \& Cho, 1999; Barkema \& Vermeulen, 1998; Slangen \& Hennart, 2008), country-related risks (Barkema \& Vermeulen, 1998; Demirbag et al., 2008), and difficulty with finding companies to take over (Slangen \& Hennart, 2008; Slangen, 2011).

There are not many studies, however, which discuss the evaluations of alternative establishment modes in foreign markets based on the identification of outcomes reported by investors (Shaver, 1998; Shrader, 2001; Datta et al., 2002; Shimizu et al., 2004, Slangen \& Hennart, 2008; Szałucka, 2010). In particular, there is not enough work on evaluating alternative foreign establishment modes ex-post (post-investment efficiency). When such work is undertaken, it relates primarily to the outcomes of subsidiary operations. Some studies point out that subsidiaries built from scratch are more successful than subsidiaries created as a result of taking over an already existing company as the investing company incurs high costs resulting from the integration of the two companies, which may not always deliver expected results (Hennart, Kim, \& Zeng, 1998; Woodcock, Beamish, \& Makino, 1994). Other studies, on the other hand, consider acquisitions to be superior, as they allow a company to limit the so-called cost of being new (liability of newness) resulting from the lack of knowledge and experience in operating on the host country market (Pennings, Barkema, \& Douma, 1994). In fact, there are hardly any studies based on empirical research which show the relationship between the investor's chosen establishment 
mode and their competitiveness, or the link between the foreign establishment mode choice and its potential outcomes (benefits) in the context of building the investing company competitiveness. The nature of these benefits should, of course, be considered in relation to the motives of companies undertaking FDI. The goals which motivate FDI are also the areas of the FDI impact, where an improvement in the competitiveness potential may be identified. It can be assumed that the establishment mode choice will depend on the objectives of an investment project and that the effectiveness of meeting a specific objective will vary depending on the establishment mode chosen.

\section{MATERIAL AND METHODS}

The results presented in this article come from a study conducted between 2012 and 2013. It covered 622 enterprises based in the Republic of Poland, which engaged their capital abroad through direct investment. All of them, regardless of their ownership of capital, had the status of Polish companies according to the current laws. The bulk of these companies held only Polish capital (61.7\%). The remaining 38.3\% were companies with foreign capital, with only $26.3 \%$ of them having solely foreign capital $(26.3 \%$ with majority ownership and $42.1 \%$ with minority ownership). The research sample was selected in a non-random way (target selection) ${ }^{2}$. The study used a direct interview method and was conducted by interviewers from a market research company using a standardised questionnaire developed by the research team. The questionnaire part related to the research area described in this study contained only closed multiple choice questions but allowed the respondents to add their own options. 64 questionnaires were filled out correctly, which meant a return rate of $10.3 \%$.

The companies which participated in the study had completed a total of 278 FDI projects. Out of these, 144 projects had been undertaken as acquisitions $(51.8 \%)$ and 134 as greenfield investments (48.2\%). The bulk of investors who chose acquisitions decided to buy part of the foreign company shares ( 96 projects), whereas 48 investors acquired all the shares in foreign companies.

Most investors participating in the survey decided to engage their capital in host country markets solely by investing from scratch ( 37 out of 64 respondents indicated this entry mode). 13 respondents indicated that the entry was made solely by purchasing part or all of the foreign company shares. The remaining 14 enterprises completed greenfield investment projects, as well as acquisitions of foreign companies. Research results presented later in this article refer to two out of three groups included in this survey: enterprises which have chosen only greenfield investments and those which entered foreign markets only via acquisitions. Excluding from the analysis those enterprises which made both foreign acquisitions and greenfield investments is dictated by the fact that it cannot be definitely said to what extent each of the establishment mode choice influenced the investing enterprises' level of competitiveness.

The results obtained from the study were analysed using impact indicators $(w)$ calculated as the arithmetic mean of numerical values assigned to a given response. They

\footnotetext{
2 Polish data protection laws prevent researchers from accessing the database of Polish companies - foreign direct investors held by state institutions (Central Statistical Office and the National Bank of Poland). The choice of elements for the research sample and the lack of accurate identification of the collective structure suggest caution in formulating conclusions. There is no scientific basis for the generalisation of conclusions based on the results obtained in the course of the study.
} 
ranged from -1 to 1 . It was assumed that the values in the range of $-1 \leq w<-0.5$ denote a negative impact, where: $-0.5 \leq w<0$ - means a moderately negative impact, $w=0-$ means no impact, $0>w \geq 0.5$ - means a moderately positive impact, $0,5>w \geq 1$ - means a positive impact. Fisher's exact test was also used to meet the required assumptions with the assumed significance level at $p<0.05^{3}$. Statistical calculations were performed using the IBM SPSS Statistics software version 21.0.0.1.

\section{RESULTS AND DISCUSSION}

Based on the study, it can be concluded that FDI contributed to improving enterprise competitiveness to a different degree among the main competitors both in the domestic and foreign markets. It is interesting to note that the scale of FDI positive impact on competitiveness was higher among the main competitors operating on foreign markets.

It follows from the analysis of responses of the companies grouped by their establishment mode choice that the positive change in their competitiveness compared to their main competitors on the home market was more often identified by companies which entered the host country market via greenfield investments $(57.1 \%)$. It should also be noted that $45.7 \%$ of all the investors believed the impact of these investments on competitiveness was moderately positive. Only $11.4 \%$ of the companies in this group declared achieving a significant improvement in competitiveness (Figure 1).

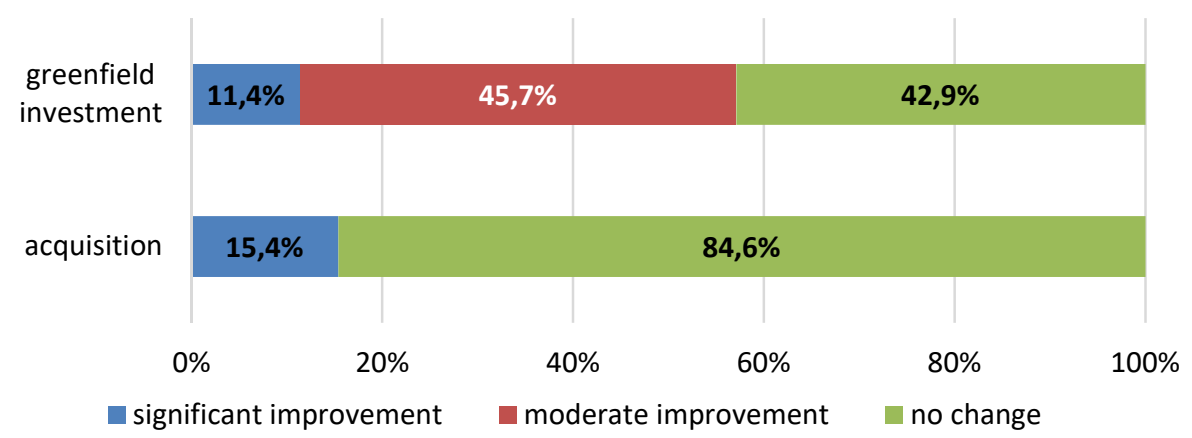

Figure 1. An evaluation of FDI impact on the competitiveness of the studied enterprises on the domestic market

Source: own elaboration based on research results.

It is interesting that a significant positive change in competitiveness was slightly more common among respondents who opted for FDI through an acquisition of part or all of a direct investment enterprise. However, the differences in the percentage of indications for this variant of responses between the groups were marginal. Slightly over $15 \%$ of the respondents in this group believed that the change in competitiveness was significant, but according to the remaining companies in this group their competitiveness did not change ( $84.6 \%$ of indications).

\footnotetext{
${ }^{3}$ The use of Fisher's exact test instead of the Chi-Square test of Independence was dictated by too small empirical numbers $(<5)$ in the independence table cells.
} 
The reasons for this clearly higher evaluation of greenfield investments when compared to acquisitions can be attributed to the different nature of the analysed establishment modes, which impacts the potential results in building competitiveness on the home market. One of the fundamental advantages of greenfield investments is the possibility of optimal project adaptation to the needs of the investor, both in the scale and structure of the direct investment enterprise and in the adaptation to technical and economic requirements (Karaszewski \& Szałucka, 2011, p. 23) These attributes allow the investor to match and synchronise the activities carried out within the company located abroad with the activities of other companies within the organisational structure, including the parent company, and to benefit from the integration of their activities. Adapting and synchronising activities enables direct and targeted enhancement of the investor's competitiveness potential on the home market. In the case of acquisitions, the ability to adjust and synchronise activities is much more limited and depends on many factors, both internal and external ones.

The differences in the evaluation of FDI impact on enterprise competitiveness depending on the establishment mode choice are confirmed by the Fisher's exact test results. The significance of the test was 0.004 and allowed us to reject the independence hypothesis and make the assumption that the evaluation of FDI impact on the competitiveness to major home market competitors depends on the foreign establishment mode choice (greenfield investments vs. acquisitions), while confirming the differences in the evaluation of FDI impact on competitiveness between two business groups. These results indicate an advantage of greenfield investment projects over acquisitions in the fact that they have a higher positive impact on the investor's competitiveness on the home market.

The differences in the evaluation of FDI impact on the company's competitiveness depending on the establishment mode choice were also observed in relation to the main competitors in foreign markets (Figure 2). Similarly to the home market, the respondents who frequently identified a significant improvement in competitiveness as a result of FDI were the investors who entered the host country market through acquisitions (23.1\% respondents). However, the percentage of companies in this group that experienced a general improvement in competitiveness as a result of their investment was lower (only $30.8 \%$ of respondents).

A high percentage of companies among the respondents of this group which failed to observe any improvement in their competitiveness resulting from FDI may be the result of little experience among some Polish investors in conducting complex transactions of an enterprise's purchase/sale, as well as problems with managing such an entity and its integration with other companies within the organisation structure. Limited experience and insufficient management competencies of some Polish enterprises may result in significantly limited benefits from investment projects undertaken abroad via acquisitions.

$60 \%$ of the companies which decided to invest exclusively from scratch indicated that the impact on their competitiveness was positive when compared to their main competitors in foreign markets, with only $14.3 \%$ of the companies which evaluated this impact as significant. The low percentage of companies that experienced a significant improvement and a relatively high percentage of companies seeing a moderate improvement in their competitiveness may be due to a relatively slow pace of entry into the foreign market via 
greenfield investments and the accompanying gradual change in the investor's competitiveness potential. Contrary to this, an incremental change in the competitiveness potential can be expected in the case of acquisitions.

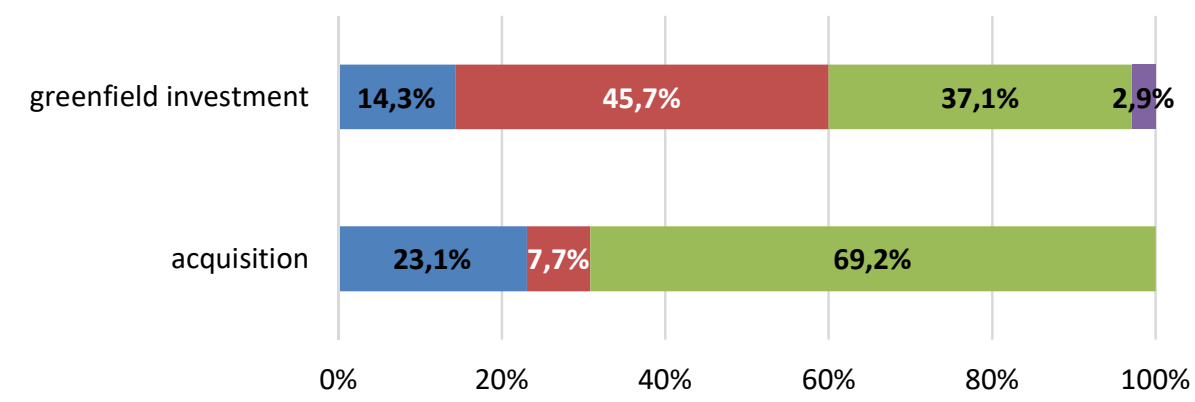

nignificant improvement $\square$ moderate improvement $\square$ no change $\square$ moderate deterioration

\section{Figure 2. An evaluation of FDI impact on the competitiveness of the studied enterprises in foreign markets \\ Source: own elaboration based on research results.}

The differences in the evaluation of FDI impact on competitiveness depending on the establishment mode choice are also reflected in statistical tests. Fisher's exact test results disproved the hypothesis that the evaluation of FDI impact on the competitiveness to major foreign competitors is independent of the establishment mode choice, suggesting statistically significant differences in the evaluation of FDI impact on competitiveness between the groups of enterprises $(p=0.040)$. From the perspective of foreign markets, positive changes in competitiveness were more frequently observed by respondents who chose to enter into foreign markets through greenfield investments. These results may be indicative of lesser benefits gained from entering foreign markets via acquisitions.

Interesting conclusions can also be drawn from the analysis of the evaluation of FDI impact on particular areas and components of the competitiveness potential among the enterprises covered by this study. Respondents' opinions suggest that regardless of the establishment mode choice, the most significant benefits were observed in 'sales and marketing' (Table 1). The evaluation of FDI impact on some of other aspects of competitiveness potential was somewhat different. Apart from the above area, direct investment companies which had been created via greenfield investments contributed mainly to the strengthening of 'intangible assets' and 'organisation and management'. Acquisitions, however, contributed to the improvement of 'intangible assets' and 'production'. Regardless of the establishment mode, the investors found the least benefits in 'research and development' and 'finance'.

A detailed analysis of FDI impact on the individual components of the competitiveness potential, however, indicates different benefits from FDI depending on the establishment mode choice. In the opinion of the respondents, direct investment companies created via greenfield investments contributed the most to the understanding of client needs and preferences ( 0.68 - the impact indicator; 1 st place), to better access to the market $(0.67$; 2nd place) greater knowledge of competitors' behaviour ( 0.61 ; 3rd place) and organisational knowledge and skills $(0.60 ; 4$ th place). The positive impact of this factor was also identified with respect to the company reputation and customer relations (both in 5 th 
place with the impact indicator of 0.54). Organisational culture, knowledge and skills in marketing and technology, the ability to achieve economies of scale and the ability to react quickly to market changes (0.51), all ranked 6th in this hierarchy.

Greenfield investments contributed more than acquisitions to strengthening the following competitiveness elements: understanding customer needs and preferences, competitor behaviour, knowledge and skills within an organisation, the ability to scale and reliability in terms of deliveries. Investors in this group ranked relatively high FDI benefits in building company reputation and creating an appropriate organisational culture. The areas of positive FDI impact identified by this group of investors also include the following: gaining experience in organising and managing companies located abroad, optimising the scope of their activity and achieving economies of scale. The respondents' evaluation of FDI impact on the individual components of competitiveness potential compared to the group of enterprises which made only acquisitions suggests that the enterprises which created a company abroad from scratch had greater benefits from their investment activity through FDI as they identified no less than fourteen components which had a positive impact ${ }^{4}$. As for the impact on the other components of competitiveness potential, the improvement was moderately positive.

An analysis of the survey results for the respondents who undertook FDI via acquisitions provides different conclusions. According to the respondents in this group, acquisitions of foreign companies were mainly used to increase the access to foreign markets $(0.54 ; 1$ st place). Investors ranked knowledge and skills in marketing and understanding customer needs and preferences $(0.50)$ second. Compared with greenfield investment projects, acquisitions contributed more to the improvement customer relations and employee qualifications. These elements were ranked 3rd by the investors in this group, but they ranked 5 th and 9th, respectively among the investors investing solely in greenfield projects.

Particular attention should also be given to high ratings attributed to FDI impact on the brand of products and services, the ability to react quickly to market changes and the insight into the competitor behaviour - they all ranked 4th with an impact indicator of 0.42 . Investors in this group also evaluated high FDI impact on gaining access to intellectual property rights and improving their relations with suppliers. These components were ranked 5 th together with organisational knowledge and skills and company reputation (0.38).

In addition to this, when compared to greenfield investment projects, acquisitions proved to be a more effective instrument for building competitiveness potential in the following areas: innovation in production processes (7th place against 20th place), other relations with the external environment (6th place against 18th), convenience of location in terms of legal norms and economic conditions of operation (10th place against 21th), the degree of risk diversification and the access to workforce (8th place against 14th). The enterprises in this group also noticed greater FDI benefits in terms of knowledge and skills in quality (6th place against 10th), the level of technological advancement, innovations in products and services (7th place against 11th), access to equity capital (8th place against 12th), as well as the ability to coordinate resources effectively (9th place against 13th).

\footnotetext{
${ }^{4}$ Based on the value of the impact indicator. See more in the explanations for Table 1.
} 
Table 1. FDI impact on the components of competitiveness potential among the studied enterprises depending on their establishment mode choice

\begin{tabular}{|c|c|c|c|c|}
\hline \multirow[b]{2}{*}{ Specifications } & \multicolumn{2}{|c|}{ Greenfield } & \multicolumn{2}{|c|}{ Acquisition } \\
\hline & $\begin{array}{l}\text { Indicator } \\
\text { value }\end{array}$ & $\begin{array}{l}\text { Posi- } \\
\text { tion }\end{array}$ & $\begin{array}{l}\text { Indicator } \\
\text { value }\end{array}$ & $\begin{array}{l}\text { Posi- } \\
\text { tion }\end{array}$ \\
\hline Research and development & 0.35 & $\mathbf{v}$ & 0.28 & $\mathbf{v}$ \\
\hline research and development facilities & 0.30 & 19 & 0.18 & 14 \\
\hline knowledge and skills in creating innovation & 0.37 & 15 & 0.25 & 11 \\
\hline innovations in products and services & 0.44 & 11 & 0.33 & 7 \\
\hline innovations in production processes & 0.29 & 20 & 0.33 & 7 \\
\hline Production / services & 0.43 & III & 0.32 & III \\
\hline production (service) facilities & 0.34 & 17 & 0.25 & 11 \\
\hline ability to achieve economies of scale & 0.53 & 6 & 0.27 & 10 \\
\hline level of technological advancement & 0.44 & 11 & 0.33 & 7 \\
\hline knowledge and skills in technology & 0.53 & 6 & 0.38 & 5 \\
\hline employee qualifications & 0.49 & 9 & 0.46 & 3 \\
\hline access to workforce & 0.39 & 14 & 0.31 & 8 \\
\hline access to natural resources & 0.17 & 23 & 0.25 & 11 \\
\hline access to materials and half-finished products / auxiliary services & 0.30 & 19 & 0.17 & 15 \\
\hline knowledge and skills in logistics & 0.51 & 7 & 0.35 & 6 \\
\hline relationships with suppliers & 0.49 & 9 & 0.38 & 5 \\
\hline quality assurance system & 0.50 & 8 & 0.35 & 6 \\
\hline knowledge and skills in quality & 0.47 & 10 & 0.35 & 6 \\
\hline Sales and marketing & 0.58 & 1 & 0.45 & $\mathrm{I}$ \\
\hline access to the market & 0.67 & 2 & 0.54 & 1 \\
\hline understanding customer needs and preferences & 0.68 & 1 & 0.50 & 2 \\
\hline insight into competitor behaviour & 0.61 & 3 & 0.42 & 4 \\
\hline an ability to ensure reliable deliveries & 0.51 & 7 & 0.27 & 10 \\
\hline knowledge and skills in marketing & 0.53 & 6 & 0.50 & 2 \\
\hline customer relations & 0.54 & 5 & 0.46 & 3 \\
\hline an ability to react quickly to market changes & 0.53 & 6 & 0.42 & 4 \\
\hline Finances & 0.37 & IV & 0.24 & VI \\
\hline equity capital & 0.42 & 12 & 0.31 & 8 \\
\hline access to foreign capital & 0.36 & 16 & 0.15 & 16 \\
\hline cost level & 0.24 & 22 & 0.21 & 13 \\
\hline knowledge and skills in financial management & 0.42 & 12 & 0.23 & 12 \\
\hline degree of risk diversification & 0.39 & 14 & 0.31 & 8 \\
\hline Intangible and legal assets & 0.44 & II & 0.40 & II \\
\hline company reputation & 0.54 & 5 & 0.38 & 5 \\
\hline brand of products and services & 0.49 & 9 & 0.42 & 4 \\
\hline intellectual property rights & 0.29 & 20 & 0.38 & 5 \\
\hline Organisation and management & 0.44 & II & 0.30 & IV \\
\hline enterprise size & 0.51 & 7 & 0.31 & 8 \\
\hline organisational culture & 0.53 & 6 & 0.35 & 6 \\
\hline organisational structure & 0.47 & 10 & 0.31 & 8 \\
\hline organisational knowledge and skills & 0.60 & 4 & 0.38 & 5 \\
\hline interpersonal relations in an enterprise & 0.40 & 13 & 0.27 & 10 \\
\hline an ability to allocate resources efficiently & 0.42 & 12 & 0.21 & 13 \\
\hline an ability to coordinate resources efficiently & 0.40 & 13 & 0.29 & 9 \\
\hline $\begin{array}{l}\text { convenience of location in terms of legal norms and economic con- } \\
\text { ditions of operation }\end{array}$ & 0.28 & 21 & 0.27 & 12 \\
\hline other relations with the external environment & 0.32 & 18 & 0.35 & 6 \\
\hline
\end{tabular}

Source: own study on the basis of survey results. 
It is worth pointing out that only with three components of competitiveness potential (innovation in products and services, intellectual property rights and other relationships with the environment) FDI impact as measured by the value of the applied indicator was higher than the value calculated on the basis of the indications in the second group. In addition to this, only one component of competitiveness potential was believed to have a positive impact (the value of the impact factor $>0.50$ ). The above results also lead to a conclusion that the group of companies which undertook FDI only via acquisitions benefited less from their operations on foreign markets when compared to the group that made only greenfield investments.

The differences in the evaluation of FDI impact on the individual components of competitiveness potential depending on the establishment mode choice are also confirmed by the results of Fisher's exact test. The significance of this test revealed the relationship between the establishment mode choice and the evaluation of FDI impact on the components of competitiveness potential for 6 out of 39 analysed components. Significant statistical differences were observed with respect to the ability to achieve economies of scale $(p=0.039)$, the access to materials and half-finished products / auxiliary services $(p=0.008)$, customer relations $(p=0.019)$, the ability to respond to market changes $(p=0.003)$, corporate reputation $(p=0.037)$ and the ability to allocate resources effectively $(p=0.035)$.

A detailed analysis of the frequency of individual evaluations of FDI impact on selected components of competitiveness potential shows that FDI undertaken via greenfield investments was a more effective instrument for building all the above-mentioned components of competitiveness potential than acquisitions. The greatest differences in the evaluation of FDI impact on selected components were observed in respect of economies of scale, the access to materials and semi-finished products and the ability to allocate resources efficiently. For over $83 \%$ of enterprises, greenfield projects contributed to improving their ability to achieve economies of scale (respondents rated the change as positive or moderately positive) against only $46.2 \%$ of investors who entered the markets through acquisitions.

In terms of the ability to allocate resources effectively and the access to materials and half-finished products/ancillary services, $72.2 \%$ and $54.3 \%$ investors undertaking only greenfield investments respectively observed an improvement in the competitiveness potential against merely $33.3 \%$ and $16.7 \%$ respondents using acquisitions as an establishment mode in foreign markets. With the vast majority of components, however, except for 'the ability to achieve economies of scale', the percentage of companies which indicated a positive change was greater among enterprises undertaking acquisitions than those that invested from scratch. A larger percentage of companies which observed only a significant change in their potential may be the result of an incremental rather than gradual increase in their potential when taking over a foreign company. FDI impact on the remaining 33 components of competitiveness potential was similar between the two groups of companies, and the test results did not justify a rejection of the null hypothesis with two independent variables.

Based on the studies, it can be concluded that there are no significant differences as far as the importance of FDI for building competitiveness potential depending on the establishment mode choice (Figure 3). In the opinion of both studied groups of enterprises, FDI is an important factor in building their competitiveness potential. However, a slightly larger proportion of investors who undertook greenfield investments responded that FDI proved to be 
very important in building competitiveness potential compared to $15.4 \%$ investors who made foreign acquisitions. This confirms previous research findings pointing to the fact that greenfield projects brought greater benefits to the studied investors. However, a group of investors who made greenfield investments pointed out less frequently that FDI proved to be important for building their competitiveness potential $-40.0 \%$ vs. $53.8 \%$ of such responses in the group of investors who made foreign acquisitions. Investors who took over foreign companies pointed more often to the fact that foreign investment did not play a role in building their competitiveness potential. Fisher's exact test results also confirmed negligible statistical differences in the evaluation of the importance of FDI in building a company's competitiveness potential depending on their establishment mode choice $(p=0.625)$.

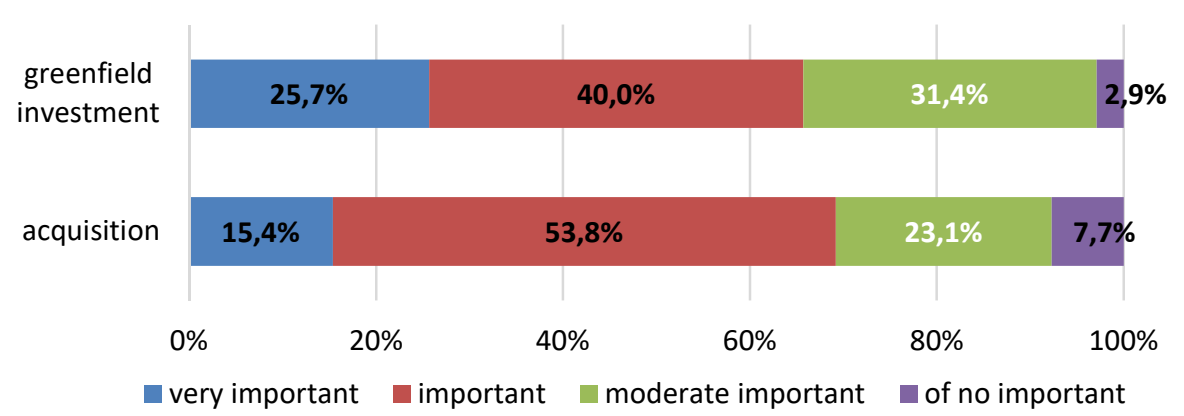

Figure 3. The importance of foreign direct investment in building competitiveness potential among studied enterprises by their entry mode into the host market

Source: own elaboration based on survey results.

\section{CONCLUSIONS}

Foreign investment activity among Polish companies contributes to the improvement of their competitiveness. This positive FDI impact on competitiveness was more apparent among the investors in relation to competitors on foreign markets rather than competitors on the home market. The studied companies generally indicated a moderately positive impact of their investments on their competitiveness.

The research results also show that in the case of companies which undertook FDI from scratch, these investments contributed to improving their competitiveness on the Polish as well as on foreign markets. Relatively lesser FDI benefits were observed among those companies which entered foreign markets via acquisitions, which may have its explanation in the nature of the purchase/sale transaction and the accompanying difficulties.

The differences between the two groups of enterprises in the evaluation of FDI impact on competitiveness does not justify rejecting the first hypothesis (H1), which claims that 'the evaluation of FDI impact on the competitiveness of Polish companies on both home and foreign markets depends on the foreign establishment mode choice'.

The results of the study point to the differences in the evaluation of FDI impact on the individual components of competitiveness potential depending on the foreign establishment mode. Therefore, there are no grounds for the rejection of the second hypothesis $(\mathrm{H} 2)$, which says that 'the benefits of FDI impact on the components of competitiveness potential depend on the foreign establishment mode'. 
The most diverse benefits of internationalised operations were achieved by companies which had undertaken FDI via greenfield investments. Within this group of companies, FDI had the largest impact on the following components of competitiveness potential: sales and marketing, intangible and legal assets, organisation and management.

The companies which chose the acquisition of all or part of a foreign enterprise estimated that the investment projects they undertook abroad had a significant impact on gaining access to the market. These companies perceived a stronger FDI impact on improving innovation in production processes, gaining access to intellectual property rights and improving relations with the wider environment.

Based on the results of the study, it can be said that the allocation of capital in the form of FDI significantly affects the competitiveness potential of Polish foreign direct investors. This is the case regardless of the establishment mode choice. In conclusion, foreign direct investment should be seen as an effective tool for building a company's competitiveness.

As mentioned above, the data protection laws in Poland prevent researchers from accessing the database of Polish companies which are foreign direct investors (such databases are owned by the Central Statistical Office and the National Bank of Poland). The method of selecting companies for a research sample and the lack of accurate identification of the structure of the examined population calls for caution when generalising the above conclusions. It is very likely, however, that they are close to being factual.

The results of this study may be a starting point for further research on the impact of FDI on competitiveness, particularly through foreign acquisitions. It should be assumed that as Polish companies gain experience on the international stage, this mode of entry will be chosen by investors more frequently. Furthermore, it would be interesting to analyse data on the performance of the companies making FDI as well as their foreign subsidiaries. Finally, future investigation can also try to explore more deeply the foreign establishment mode choice as a variable affecting the company's global competitive advantage from the resource-based view of the firm.

\section{REFERENCES}

Arslan, A., \& Larimo, J. (2011). Greenfield investments or acquisitions: Impacts of institutional distance on establishment mode choice of multinational enterprises in emerging economies. Journal of Global Marketing, 24(4), 345-356. https://doi.org/10.1080/08911762.2011.602323

Barkema, H.G., \& Vermeulen, F. (1998). International Expansion Through Start-up or Acquisition: a Learning Perspective. Academic Management Journal, 41(1), 7-26. https://doi.org/10.2307/256894

Brouthers, K.D., \& Brouthers, L.E. (2000). Acquisition or greenfield start-up? Institutional, cultural and transaction cost influences. Strategic Management Journal, 21(1), 89-97. https://doi.org/10.1002/(SICI)1097-0266(200001)21:1<89::AID-SMJ85>3.0.CO;2-8

Brouthers, K.D., \& Hennart, J.-F. (2007). Boundaries of the firm: Insights from international entry mode research. Journal of Management, 33(3), 395-425. https://doi.org/10.1177/0149206307300817

Bruning, E.R., Turtle, H.J., \& Buhr, K. (1997). Characterizing mode of entry for Canadian foreign direct investment into the United States: 1980-1989. International Journal of Commerce \& Management, 7(3/4), 56-80.

Caves, R.E., \& Mehra S.K. (1986). Entry of foreign multinationals into the US manufacturing industries. In M.E. Porter (Ed.), Competition in global industries (pp. 449-481). Boston: Harvard Business School Press. 
Cho, K.R., \& Padmanabhan, P. (1995). Acquisition versus new venture: The choice of foreign establishment mode by Japanese firms. Journal of International Management, 1(3), 255-286.

Daszkiewicz, N., \& Wach, K. (2013). Małe i średnie przedsiębiorstwa na rynkach międzynarodowych, Kraków: Wydawnictwo Uniwersytetu Ekonomicznego w Krakowie.

Datta, D.K., Herrmann, P., \& Rasheed, A.A. (2002). Choice of foreign market entry mode: critical review and future directions. Advances in Comparative International Management, 14, 85-153.

Demirbag, M., Tatoglu, E., \& Glaister, K.W. (2008). Factors affecting perceptions of the choice between acquisition and greenfield entry: The case of Western FDI in an emerging market. Management International Review, 48(1), 5-38. https://doi.org/10.1007/s11575-008-0002-3

Demirbag, M., Tatoglu, E., \& Glaister, K.W. (2009). Equity-based entry modes of emerging country multinationals: Lessons from Turkey. Journal of World Business, 44(4), 445-462. https://doi.org/10.1016/j.jwb.2008.11.009

Dikova, D., \& Brouthers, K.D. (2016). International establishment mode choice: past, present and future. Management International Review, 56(4), 489-530.

Gorynia, M. (2007). Strategie zagranicznej ekspansji przedsiębiorstw. Warszawa: PWE.

Gorynia, M., Nowak, J., Trąpczyński, P., \& Wolniak, R. (2015a). Establishment mode choices of emerging multinationals: evidence from Poland. Managing Global Transitions, 13(2), 101-124.

Gorynia, M., Nowak, J., Trąpczyński, P., \& Wolniak, R. (2015b). Outward FDI of Polish firms: The role of motives, entry modes and location factors. Journal of East European Management Studies, 20(3), 328-359.

GUS (2017). Działalność podmiotów posiadajqqcych jednostki zagraniczne w 2015 r. Warszawa.

Harzing, A.-W. (2002). Acquisitions versus greenfield investments: International strategy and management of entry modes. Strategic Management Journal, 23(3), 211-227. https://doi.org/10.1002/smj.218

Hennart, J.-F., Kim, D.-J., \& Zeng M. (1998). The impact of joint venture status on the longevity of Japanese stakes in U.S. manufacturing affiliates. Organization Science, 9(3), 382-395. https://doi.org/10.1287/orsc.9.3.382

Hennart, J.-F., Larimo, J., \& Chen S.-F. (1996). Does national origin affect the propensity of foreign investors to enter the United States through acquisitions?. Finland: Proceedings of the University of Vaasa (Discussion paper no. 189).

Hennart, J.-F., \& Park, Y.R. (1993). Greenfield vs. acquisition: the strategy of Japanese investors in the United States. Management Science, 39(9), 1054-1070. https://doi.org/10.1287/mnsc.39.9.1054

Holtbrügge, D., \& Berningn, S.C. (January, 2018). Market entry strategies and performance of Chinese firms in Germany: The moderating effect of home government support. Management International Review. https://doi.org/10.1007/s11575-017-0334-y

Jiménez-Burillo, S., \& Jiménez-Moreno, J.J. (2013). The Role of the Top Management Team in the Choice of Entry Modes - Theoretical Perspective. Entrepreneurial Business and Economics Review, 1(2), 51-58. https://doi.org/10.15678/EBER.2013.010205

Karaszewski, W., \& Szałucka, M. (2011). Bezpośrednie inwestycje zagraniczne - greenfield versus brownfield. Przeglqad Organizacji, 5, 23-26.

Kowalewski, O., \& Radło, M-J. (2014). Determinants of foreign investment and entry modes of Polish multinational enterprises: A new perspective on internationalization. Communist and Post-Communist Studies, 47(3-4), 365-374.

Larimo, J. (2003). Form of investment by Nordic firms in world markets. Journal of Business Research, F56(10), 791-803.

Padmanabhan, P., \& Cho, K.R. (1999). Decision-specific experience in foreign ownership and establishment strategies: Evidence from Japanese firms. Journal of International Business Studies, 30(1), 25-44. 
Pennings, J.M., Barkema, H., \& Douma, S. (1994). Organizational learning and diversification. Academy of Management Journal, 37(3), 608-640.

Shaver, J.M. (1998). Accounting for endogeneity when assessing strategy performance: does entry mode choice affect FDI survival?. Management Science, 44(4), 571-585. https://doi.org/10.1287/mnsc.44.4.571

Shen, Z., \& Puig, F. (November, 2017). Spatial dependence of the FDI Entry Mode Decision: Empirical Evidence From Emerging Market Enterprises. Management International Review, https://doi.org/10.1007/s11575-017-0332-0

Shimizu, K., Hitt, M.A., Vaidyanath, D., \& Pisano, V. (2004). Theoretical foundations of cross-border mergers and acquisitions: A review of current research and recommendations for the future. Journal of International Management, 10(3), 307-353. https://doi.org/10.1016/j.intman.2004.05.005

Shrader, R. (2001). Collaboration and Performance in Foreign Markets: the Case of Young Hightechnology Manufacturing Firms. Academy of Management Journal, 44(1), 45-60. https://doi.org/10.2307/3069336

Slangen, A. (2011). A Communication-based Theory of the Choice between Greenfield and Acquisition Entry. Journal of Management Studies, 48(8), 1699-1726. https://doi.org/10.1111/j.1467-6486.2011.01013.x

Slangen, A. (2013). Greenfield or Acquisition Entry? The Roles of Policy Uncertainty and MNE Legitimacy in Host Countries. Global Strategy Journal, 3(3), 262-280. https://doi.org/10.1111/j.2042-5805.2013.01056.x

Slangen, A., \& Hennart, J.-F. (2007). Greenfield or acquisition entry: a review of the empirical foreign establishment mode literature. Journal of International Management, 13(4), 403-429. https://doi.org/10.1016/j.intman.2007.08.001

Slangen, A., \& Hennart, J.-F. (2008). Do Foreign Greenfields Outperform Foreign Acquisitions or vice versa? An perspective. Journal of Management Studies, 45(7), 1301-1328. https://doi.org/10.1111/j.1467-6486.2008.00794.x

Szałucka, M. (2008). Wpływ bezpośrednich inwestycji zagranicznych na konkurencyjność polskich inwestorów. In W. Karaszewski (Ed.), Bezpośrednie inwestycje zagraniczne polskich przedsiębiorstw (pp. 171-240). Toruń: Wydawnictwo TNOiK "Dom Organizatora".

Szałucka, M. (2010). Acquisition versus Greenfield Investment: The Impact on the Competitiveness of Polish Companies. Journal of Business Management, 3, 3-15.

UNCTAD (2009). Training Manual on Statistics for FDI and the Operations of TNCs. New York and Geneva: United Nations.

UNCTAD (2016). World Investment Report 2016. Investor Nationality: Policy Challenges. New York and Geneva: United Nations.

Vermeulen, F., \& Barkema, H.G. (2001). Learning through acquisitions. Academic Management Journal, 44(3), 457-476.

Wach, K. (2012). Europeizacja małych i średnich przedsiębiorstw: rozwój przez umiędzynarodowienie. Warszawa: PWN.

Werner, S. (2002). Recent Developments in International Management Research: A Review of 20 Top Management Journals. Journal of Management, 28(3), 277-305. https://doi.org/10.1177/014920630202800303

Woodcock, C.P., Beamish, P., \& Makino, S. (1994). Ownership-based Entry Mode Strategies and International Performance. Journal of International Business Studies, 25(2), 253-274.

Zejan, M. (1990). New Ventures or Acquisitions: the Choice of Swedish Multinational Enterprises. Journal of Industrial Economics, 38(3), 349-355. 


\section{Authors}

The contribution of co-authors is: M. Jaworek 30\%, W. Karaszewski 30\%, M. Szałucka 40\%.

\section{Małgorzata Jaworek}

Professor of Nicolaus Copernicus University in Toruń. Her research interests include internationalisation of Polish enterprises in the form of foreign direct investment, foreign direct investment in the privatisation process of the Polish economy, evaluation of FDI and FDI inflows in The Kuyavian-Pomeranian Voivodeship.

Correspondence to: $\mathrm{dr}$ hab. inż. Małgorzata Jaworek, prof. UMK, Nicolaus Copernicus University in Toruń, Faculty of Economic Sciences and Management, Gagarina, 13a, 87-100 Toruń, Poland, e-mail: mjaworek@umk.pl

\section{Włodzimierz Karaszewski}

Professor of Nicolaus Copernicus University in Toruń. His research interests include internationalisation of Polish enterprises in the form of foreign direct investment, market transformation of Polish enterprises and FDI inflows in The Kuyavian-Pomeranian Voivodeship.

Correspondence to: dr hab. Włodzimierz Karaszewski, prof. UMK, Nicolaus Copernicus University in Toruń, Faculty of Economic Sciences and Management, Gagarina, 13a, 87-100 Toruń, Poland, e-mail: wkaras@umk.pl

\section{Małgorzata Szałucka}

Associate Professor of Nicolaus Copernicus University in Toruń. Her research interests include internationalisation of Polish enterprises in the form of foreign direct investment, company competitiveness and FDI inflows in The Kuyavian-Pomeranian Voivodeship.

Correspondence to: dr Małgorzata Szałucka, Nicolaus Copernicus University in Toruń, Faculty of Economic Sciences and Management, Gagarina, 13a, 87-100 Toruń, Poland, e-mail: mszalucka@umk.pl

\section{Acknowledgements and Financial Disclosure}

The article came into being within the project no. N N112 322338 entitled 'Investment Activity of Polish Enterprises Abroad - Factors and Effects' financed by the Ministry of Science and Higher Education under the decision No. 3223/B/H03/2010/38 conducted by the following team: W. Karaszewski (head), M. Jaworek, M. Kuzel, M. Szałucka, A. Szóstek and M. Kuczmarska in the years 2012-2013.

The authors would like to thank the anonymous referees for their useful comments, which allowed to increase the value of this article.

\section{Copyright and License}

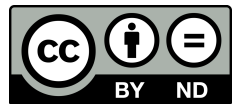

This article is published under the terms of the Creative Commons Attribution - NoDerivs (CC BY-ND 4.0) License http://creativecommons.org/licenses/by-nd/4.0/

\section{Published by the Centre for Strategic and International Entrepreneurship - Krakow, Poland}

